\title{
SENAM BERSAMA KADER-KADER PKK DESA BONTOCINI
}

\author{
EKA SERLI PRATIWI \\ 9173770410318 \\ ekaserlipratiwii@gmail.com
}

1. Bentuk Kegiatan

$>$ Senam bersama kader PKK dan masyarakat desa Bontocini.

2. Lokasi

> Lapangan olahraga desa Bontocini.

3. Hari/Tanggal dan Waktu

$>$ Hari Minggu, setelah Ashar - selesai.

4. Peserta yang Dilibatkan

> Kader PKK desa Bontocini

> Mahasiswa KKLP Yapti Jeneponto

$>$ Anak-anak

5. Alasan diadakannya

> Alasan diadakannya kegiatan ini adalah untuk menjaga kebugaran jasmani. selain itu, senam juga dapat memperkuat tulang, membantu menormalkan aliran darah dan melatih urat saraf yang kaku serta meningkatkan kesehatan jantung dan stamina tubuh.

6. Tujuan dan Manfaat

$>$ Tujuan dan manfaat senam yaitu untuk membantu meningkatkan kebugaran jasmani serta dapat menjaga stamina tubuh.

7. Deskripsi Kegiatan

> Kegiatan senam ini dilakukan setelah sholat Ashar tempatnya yaitu di Lapangan Olahraga desa Bontocini. 